\title{
Makna Iman dalam Perjanjian Baru
}

\author{
Alvin Budiman Kristian \\ Sekolah Tinggi Teologi Excelsius
}

\begin{abstract}
This study aims to explain or explain about the meaning of faith in the New Testament starting from understanding, the meaning of faith in the New Testament, to the application of New Testament figures to be applied in everyday life. the terms faith and trust in the Bible often contain the following components of meaning: Believe and accept that something is true, rely on or entrust yourself, be faithful, and be obedient.
\end{abstract}

Keywords: Faith, Believe, New Testament

\begin{abstract}
Abstrak
Penelitian ini bertujuan untuk menjelaskan atau menjabarkan tentang seputar makna iman dalam Perjanjian Baru mulai dari pengertian, makna iman dalam Perjanjian Baru, hingga aplikasi dari tokoh Perjanjian Baru untuk diterapkan dalam kehidupan sehari-hari. istilah iman dan percaya dalam Alkitab sering mengadung komponen-komponen makna sebagai berikut: Percaya dan menerima bahwa sesuatu itu benar, mengandalkan atau mempercayakan diri, setia, dan taat.
\end{abstract}

Kata Kunci: Iman, Kepercayaan, Perjanjian Baru 


\section{PENDAHULUAN}

Iman dan kepercayaan adalah dua kata yang seringkali digunakan secara terpisah ataupun berpadanan. Iman kadangkadang diibaratkan sebagai salah satu sisi dari uang logam. Sebagai mana pendapat Price yang mengatakan, "Iman adalah satu sisi dari uang logam." Dua kata tersebut sering muncul di dalam Alkitab. Jumlah iman pada Alkitab Terjemahan Baru baik PL dan PB adalah 170 kata dalam 154 ayat. $^{2}$

Kebanyakan orang menyangka iman dan kepercayaan itu sama. Sebagian besar manusia berpikir bahwa kepercayaan itu iman dan iman itu kepercayaan. Secara umum yang disebut iman atau percaya adalah menerima kesaksian orang lain. ${ }^{3}$ Tidak dapat disangkal, bahwa unsur arti yang umum tadi yaitu "menerima kesaksian orang lain" terdapat juga di dalam pengertian "iman" atau "percaya" Alkitabiah. Roma 10:17 mengatakan "Jadi, iman timbul dari pendengaran, dan pendengaran oleh firman Kristus". Sehingga iman disini juga berarti "mengamini berita yang dibawa kepadanya sebagai berita yang benar". Akan tetapi iman menurut Alkitab tidak hanya berhenti di situ saja.

${ }^{1}$ Frederick K. C. Price, Cara Iman Bekerja (Jakarta: Yayasan Perkabaran Injil), 7.

2“Iman," Alkitab SABDA, diakses pada 15 $\begin{array}{llll}\text { Maret } 2015 & \text { Pk. } & 12.34 \text {, }\end{array}$ alkitab.sabda.org/lexicon.php?word=iman\#sum_coun t.
Apakah sebenarnya iman itu? "Iman adalah dasar dari segala sesuatu yang kita harapkan dan bukti dari segala sesuatu yang tidak kita lihat" (Ibr. 11:1). Iman mengadung dua hal: (1) tindakan yang menentukan, (2) dan sikap yang terus menerus. Iman mulai sebagai tindakan sesorang yang membuang kepercayaan pada diri sendiri untuk mendapat keselamatan. ${ }^{4}$ Orang beriman yakin kepada kebenaran janji-janji kasih karunia Allah dalam Yesus Kristus dan sunguh-sungguh bergantung pada janji-janji itu. Kemudian, iman menjadi hidup seharihari dari orang itu

Kini, ternyata masih banyak orang yang tidak memiliki iman. Jangankan memiliki iman, masalah tentang apa itu iman dan bagaimana cara kerja iman di dalam kehidupan manusia pun pasti banyak yang belum mengerti. Penulis bertujuan untuk menjelaskan atau menjabarkan tentang seputar "Makna Iman dalam Perjanjian Baru" mulai dari pengertian, makna iman dalam Perjanjian Baru, hingga aplikasi dari tokoh PB untuk diterapkan dalam kehidupan sehari-hari.

\footnotetext{
${ }^{3}$ Harun Hadiwijono, Iman Kristen (Jakarta: PT. BPK Gunung Mulia, 2001), 403.

${ }^{4}$ M. H. Simanungkalit, Alkitab Menjawab Pertanyaan tentang Iman Kristen (Jakarta: Yayasan Komunikasi Bina Kasih/OMF, 1995), 84.
} 


\section{METODOLOGI PENELITIAN}

Dalam meneliti artikel ini, penulis menggunakan metode penelitian pendekatan studi literatur.

\section{ANALISIS DAN HASIL PENELITIAN}

\section{Pengertian Iman dalam Perjanjian Baru}

Dalam PB kata benda "pistis" yang berarti iman dan kata kerja "pisteuo" keduanya muncul lebih dari 240 kali, dan kata sifat "pistos" 67 kali. ${ }^{5}$ Iman ialah sikap yang didalamnya seseorang melepaskan andalan pada segala usahanya sendiri untuk mendapat keselamatan, entah itu kebajikan, kebaikan susila atau apa saja, kemudian sepenuhnya mengandalkan Yesus Kristus dan mengharap hanya dari Dia segala sesuatu yang dimaksud oleh 'keselamatan'. 6

Kata pistis mempunyai dua arti dalam bahasa Yunani Klasik. Artinya adalah: (1) Suatu kepastian berdasarkan kepercayaan dalam diri seseorang dan pengakuannya, yang berbeda dengan pengetahuan yang bersandar pada penelitian pribadi; (2) Rasa percaya diri itu sendiri dimana kepercayaan seseorang bersandar. Kepercayaan ini lebih dari sekedar pengetahuan intelektual bahwa seseorang patut disandari; kepercayaan ini memberikan presuposisi adanya hubungan pribadi antara orang itu dengan obyek yang dipercayainya, sesuatu yang keluar dari diri sendiri untuk mau bersandar pada yang lain. ${ }^{7}$ Namun, pada umumnya orang Yunani tidak memakai kata itu dalam pengertian untuk menyatakan kepercayaan mereka kepada dewa mereka, sebab mereka menganggap kepercayaan dewa-dewa merupakan musuh manusia dan karena itu merupakan obyek rasa takut dan bukannya obyek rasa percaya. ${ }^{8}$

Sedangkan dalam Septuaginta, transisi dari penggunaan kata pistis dalam bahasa Yunani klasik menjadi bahasa yang dipakai dalam Perjanjian Baru dimana kata "percaya" atau mempercayai" sangat penting. ${ }^{9}$ Kata kerja pisteuo dalam Septuaginta lebih banyak dipakai daripada kata bendanya yang memang hanya satu kali saja dipakai seperti pengertian Perjanjian Baru itu.

\section{$\underline{\text { Makna Iman dalam Perjanjian Baru }}$}

Di dalam PB ada gagasan yang baru, yaitu iman adalah penyataan atau perkenalan Tuhan Allah yang dengan Firman-Nya itu diwujudkan di dalam diri Tuhan Yesus

${ }^{7}$ Louis Berkhof, Teologi Sistematika (Jakarta: Lembaga Reformed Injili Indonesia, 1997), 181.
Jilid I (Jakarta: Yayasan Komunikasi Bina Kasih, 2008) 431.

${ }^{6}$ Ibid
${ }^{8}$ Ibid .

${ }^{9}$ Ibid. 
Kristus. ${ }^{10}$ Dalam Markus 2:2 disebutkan, bahwa Tuhan Yesus memberitakan firman kepada orang banyak (bnd. Luk. 8:1, yang menyebutkan, bahwa Tuhan Yesus memberitakan Injil Kerajaan Allah; juga lihat Luk. 11:28). Disini Tuhan Yesus disejajarkan dengan para nabi di dalam PL, yang memberitakan Firman Tuhan Allah. Sekalipun demikian, jikalau pemberitaan para penulis Injil itu kita perhatikan, kesejajaran itu tidaklah persis sama. Ada perbedaan yang besar sekali di antara para nabi di dalam PL dan Tuhan Yesus. ${ }^{11}$

Pada waktu Yohanes Pembaptis mengutus para muridnya menghadap Tuhan Yesus untuk mengetahui apakah Yesus ini adalah orang yang benar-benar dinantinantikan Israel, atau apakah bukan, para murid Yohanes diperintahkan memberitakan kepada Yohanes apa yang telah mereka dengar dan lihat. "Pergilah dan katakanlah kepada Yohanes apa yang kamu lihat dan kamu dengar; orangbuta melihat, orang lumpuh berjalan, orang kusta menjadi tahir, orang tuli mendengar, orang mati dibangkitkan dan kepada orang miskin diberitakan kabar baik." (Luk. 7:22; bnd. Mat. 11: 4, 5). Dari sini kita dapat mengetahui, bahwa kata-kata Yesus tidak

\footnotetext{
${ }^{10}$ Harun Hadiwijono, Iman Kristen (Jakarta: PT. BPK Gunung Mulia, 2001), 42.

${ }^{11}$ Ibid., 43.

${ }^{12}$ Ibid.
}

sama dengan kata-kata para nabi di PL. Para nabi memberitakan Firman Allah yang bekerja, akan tetapi disini Firman Tuhan Yesus adalah Firman yang bekerja sendiri. Firman-Nya telah menyembuhkan para orang sakit dan telah membawa kabar kegirangan, sehingga harus disimpulkan, bahwa para murid Yohanes harus memberitakan kepada Yohanes, bahwa Firman Kristus adalah Firman Allah. ${ }^{12}$

Kata “iman" dan kata kerjanya "percaya" sering muncul dalam Alkitab, dan memang merupakan istilah penting yang menggambarkan hubungan antara umat atau seseorang dengan Allah. ${ }^{13}$ Di bawah ini akan ditinjau secara singkat makna istilah itu dalam Alkitab, khususnya dalam Perjanjian Baru. Kata "iman" yang dipakai dalam Perjanjian Baru merupakan terjemahan dari kata Yunani "pistis", sedangkan kata kerjanya "percaya adalah terjemahan dari kata "pisteuo".

Dapat disimpulkan bahwa istilah iman dan percaya dalam Alkitab sering mengadung komponen-komponen makna sebagai berikut: percaya dan menerima bahwa sesuatu itu benar, mengandalkan atau mempercayakan diri, setia, taat. ${ }^{14}$

\footnotetext{
13 "Iman dan Percaya," Ruang Istilah, diakses pada 19 Feburari 2015, Pk. 22.19, http://www.alkitab.or.id/biblika/RuangIstilah4.htm .

14 "Iman dan Percaya," Ruang Istilah, diakses pada 19 Feburari 2015, Pk. 22.25, http://www.alkitab.or.id/biblika/RuangIstilah4.htm.
} 
Kata Yunani pistis sering mempunyai komponen-komponen makna seperti di atas, baik dalam Septuaginta maupun dalam Perjanjian Baru. Dalam konteks tertentu hanya satu atau dua komponen makna yang difokuskan, dan komponen lainnya tidak ditekankan, atau malahan tidak berlaku.

Dalam PB, “iman” terutama ditujukan kepada Yesus $^{15}$, yaitu percaya kepada-Nya dan perkataan-Nya, bahwa Dia adala Tuhan dan Juruselamat, dan mempercayakan diri kepada-Nya, serta juga percaya dan menerima kebenaran Injil. Berikut ini arti pistis dan pisteuo dalam Perjanjian Baru versi Terjemahan Baru (TB) $)^{16}$ : (1) Matius 9:22: "Imanmu telah menyelamatkan engkau!” Iman disini berarti percaya kepada perkataan Yesus dan mempercayakan diri kepada-Nya. Bandingkan terjemahan dalam Alkitab Bahasa Indonesia Sehari-hari (BIS): "Karena engkau percaya kepada-Ku, engkau sembuh!”; (2) Markus 1:15: "Bertobatlah dan percayalah kepada Injil!" Kata percaya di sini menekankan komponen makna pertama, yakni bahwa Injil itu benar dan dapat dipercaya, sehingga dapat juga diterjemahkan, "Percayalah dan terimalah Injil!"; (3) Galatia 2:16: "Kami pun telah

15 Ensiklopedi Alkitab Masa Kini Jilid I (Jakarta: Yayasan Komunikasi Bina Kasih, 2008), 432.

16 "Iman dan Percaya," Ruang Istilah, diakses pada 19 Feburari 2015, Pk. 22.25, http://www.alkitab.or.id/biblika/RuangIstilah4.htm. percaya kepada Kristus Yesus, supaya kami dibenarkan karena iman dalam Kristus." Dalam ayat ini "percaya” dan "iman”, keduaduanya memiliki seluruh komponen maknanya. "Iman dalam Kristus" berarti percaya bahwa Injil tentang Yesus itu benar dan mempercayakan diri kepada Yesus dengan komitmen akan setia dan taat kepadaNya.

Selain arti yang pokok seperti diuraikan dengan beberapa contoh diatas, "iman" dalam PB menurut konteksnya kadang-kadang mempunyai arti yang berbeda, yaitu: kemampuan atau sifat baik orang Kristen, agama Kristen, ajaran atau doktrin Kristen. ${ }^{17}$ Berikut adalah contoh yang terdapat dalam PB: (1) Roma 12:6: “Jika karunia itu adalah untuk bernubuat baiklah kita melakukannya sesuai dengan iman kita." Kata "iman" disini menunjukan sifat atau kesanggupan, sehingga BIS menerjemahkannya, "Orang yang mempunyai karunia untuk mengabarkan berita dari Allah, haruslah mengabarkan berita dari Allah itu menurut kemampuan yang ada padanya."; (2) Efesus 4:5: "Satu Tuhan, satu iman, satu baptisan." Kata "iman" disini dapat diartikan sebagai agama, yakni agama Kristen; (3) Yudas 1:3 : “...

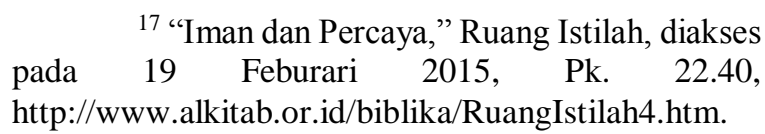
http://www.alkitab.or.id/biblika/RuangIstilah4.htm. 
supaya kamu tetap berjuang untuk mempertahankan iman yang telah disampaikan kepada orang-orang kudus." Kata yang diterjemahkan dengan "disampaikan" berarti "diteruskan", dan yang dimaksud ialah doktrin atau ajaran yang telah diteruskan dari satu generasi ke generasi lainnya. Jadi "iman" disini menunjuk pada seluruh ajaran atau doktrin Kristen.

\section{APLIKASI}

Berikut adalah aplikasi dari tokoh Perjanjian Baru yang bisa diterapkan dalam kehidupan sehari-hari:

Iman seorang perempuan yang sakit pendarahan

Salah satu tokoh dalam PB yang berkaitan dengan iman adalah seorang perempuan yang sakit pendarahan (Mat. 9:18-26; Mrk. 5:21-43; Luk. 8:40-56). Nama perempuan ini tidak pernah diketahui tapi perjalanan imannya mampu menembus ribuan tahun dan menjadi teladan bagi banyak orang. Satu hal yang kita bisa pelajari adalah ketika dia menguatkan hatinya, melangkah dengan iman seraya berkata "Asal kujamah saja jubah-Nya, aku akan sembuh." (Mrk. 5:28). Kita bisa meniru teladan iman perempuan ini, dia menguatkan hati dan datang pada Tuhan. Dia tidak lagi

\footnotetext{
18“'Dari Simon menjadi Petrus: iman yang tulus tapi...,"Martianus' Blog, diakses pada 22 $\begin{array}{lllr}\text { Februari } & 2015 & \text { Pk. } & \text { 22:43, }\end{array}$
}

mengadalkan kekuatan dan caranya sendiri untuk sembuh, tapi benar-benar pasrah dan percaya bahwa Yesum mampu menyembuhkan dengan cara-Nya.

Iman Rasul Petrus yang Goyah

Masih ingatkah kita dengan kisah Tuhan Yesus berjalan di atas air yang dicatat dalam Matius 14:22-33; Markus 6:45-52; Yohanes. 6:16-21? Markus dan Yohanes juga mencatat kisah ini tetapi hanya Matius yang mencatat pernyataan iman Petrus yang kemudian dengan berani menyusul Tuhan Yesus berjalan di atas air. ${ }^{18}$ Lihat bagaimana iman Petrus yang begitu kokoh itu, iman yang tertuju kepada Tuhan Yesus, "Tuhan, apabila Engkau itu...". Tetapi sayangnya dengan cepat iman Petrus berubah menjadi iman kepada mujizat itu, “...suruhlah aku datang kepada-Mu berjalan di atas air". Tidak salah mempercayai mujizat, tetapi jika kita menaruh iman kita kepada mujizat itu dan bukannya kepada Tuhan Yesus, maka saat datang "tiupan angin", maka kita menjadi bimbang dan tenggelam. Jangan mempercayai mujizat, percayalah kepada Kristus Sang Pembuat mujizat itu. Disini, ketulusan iman kita harus diluruskan.

Sekali waktu Petrus mengatakan demikian kepada Tuhan Yesus. "Tuhan, aku bersedia masuk penjara dan mati bersama-

http://martianuswb.com/dari-simon-menjadi-petrusiman-yang-tulus-tapi/. 
sama dengan Engkau!” (Luk. 22:33). Dan dengan segera imannya itu diuji, dan kita tahu bersama bagaimana akhirnya Petrus menyangkal Tuhan Yesus. Perhatikan ini, kita harus memiliki iman yang tulus, tetapi itu saja tidak cukup. Iman yang tulus musti disertai komitmen yang kuat dan pengabdian sepenuh hati (total submission).

\section{KESIMPULAN}

Dalam Perjanjian Baru ada gagasan yang baru, yaitu iman adalah penyataan atau perkenalan Tuhan Allah yang dengan Firman-Nya itu diwujudkan di dalam diri Tuhan Yesus Kristus.

Dapat disimpulkan bahwa istilah iman dan percaya dalam Alkitab sering mengadung komponen-komponen makna sebagai berikut: Percaya dan menerima bahwa sesuatu itu benar, mengandalkan atau mempercayakan diri, setia, dan taat.

Iman itu benar-benar supranatural. Iman itu hanya berasal dari Allah. Setiap berkat atau karunia yang kita miliki kita terima "oleh kasih karunia melalui iman" (Ef. 2:8). Iman "tidak berasal dari diri kita sendiri; itu adalah pemberian Allah". Iman itu seperti sebuah tiket. Jika iman dipisahkan dari Yesus Kristus, iman tidak bernilai. Iman tidak dapat dibangkitkan dengan pikiran alami atau dipompa seperti sebuah ban. Iman itu asli dari Allah. Iman yang sejati datang dari suatu hubungan yang intim dengan Pencipta iman kita (Ibr. 12:2). Makna iman dalam Perjanjian Baru sungguh berarti dalam kehidupan manusia. Dimana iman itu membuat kita percaya dan berhubungan kepada Tuhan yang membuat banyak mujizat dalam diri kita.

\section{DAFTAR PUSTAKA}

$\underline{\text { Buku }}$ , Ensiklopedi Alkitab Masa Kini Jilid I. Jakarta: Yayasan Komunikasi Bina Kasih/OMF, 2008.

Berkhof, Louis. Teologi Sistematika. Jakarta: Lembaga Reformed Injili Indonesia, 1997.

Hadiwijono, Harun. Iman Kristen. Jakarta: PT. BPK Gunung Mulia, 2001.

Price, Frederick K. C. Cara Iman Bekerja. Jakarta: Yayasan Perkabaran Injil, tp.th.

Simanungkalit, M. H. Alkitab Menjawab Pertanyaan tentang Iman Kristen. Jakarta: Yayasan Komunikasi Bina Kasih/OMF, 1995.

\section{$\underline{\text { Internet }}$}

"Dari Simon menjadi Petrus: iman yang tulus tapi...,"Martianus' Blog, diakses pada 22 Februari 2015 Pk. 22:43, http://martianuswb.com/dari-simonmenjadi-petrus-iman-yang-tulus-tapi/.

"Iman dan Percaya," Ruang Istilah, diakses pada 19 Feburari 2015, Pk. 22.19, http://www.alkitab.or.id/biblika/Ruang Istilah4.htm .

"Iman," Alkitab SABDA, diakses pada 15 Maret 2015 Pk. 12.34, alkitab.sabda.org/lexicon.php?word=i man\#sum_count. 